\title{
Building a Better Lawyer Discipline System: The Queensland Experience
}

Leslie Levin

University of Connecticut School of Law

Follow this and additional works at: https://opencommons.uconn.edu/law_papers

Part of the Comparative and Foreign Law Commons, Legal Ethics and Professional $\underline{\text { Responsibility Commons, and the Legal Profession Commons }}$

\section{Recommended Citation}

Levin, Leslie, "Building a Better Lawyer Discipline System: The Queensland Experience" (2006). Faculty Articles and Papers. 363. https://opencommons.uconn.edu/law_papers/363 


\section{HEINONLINE}

Citation: 9 Legal Ethics 1872006

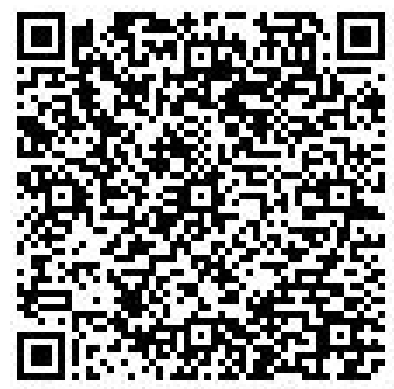

Content downloaded/printed from HeinOnline (http://heinonline.org) Tue Aug 16 13:00:39 2016

-- Your use of this HeinOnline PDF indicates your acceptance of HeinOnline's Terms and Conditions of the license agreement available at http://heinonline.org/HOL/License

-- The search text of this PDF is generated from uncorrected OCR text.

-- To obtain permission to use this article beyond the scope of your HeinOnline license, please use:

https://www.copyright.com/ccc/basicSearch.do?

\&operation $=$ go\&search Type $=0$

\&lastSearch $=$ simple\&all=on\&titleOrStdNo=1460-728X 


\title{
Building a Better Lawyer Discipline System: The Queensland Experience
}

\author{
LESLIE C. LEVIN
}

\section{Introduction}

Over the last 35 years, it has become increasingly apparent that there is something seriously wrong with lawyer discipline systems. ${ }^{1}$ Traditionally discipline was administered by lawyers' professional associations, which were slow in responding to complaints, overly lenient, and notoriously unresponsive to consumer concerns. Significant reform has not come quickly, ${ }^{2}$ but in many common law jurisdictions - after some experiments and false starts - meaningful reforms are taking hold. The magnitude of the reforms is well illustrated in Queensland, where the Legal Profession Act 2004 (Qld) ("the Act") substantially altered the structure and focus of lawyer discipline in that jurisdiction.

Before 2004, the Queensland Law Society and the Bar Association handled most discipline complaints against solicitors and barristers. Their efforts focused primarily on serious misconduct and rarely addressed the more common client complaints like failure to communicate or neglect of client matters. In 2004, the Act shifted the responsibility for lawyer discipline to an independent Legal Services Commissioner, who was effectively directed by the legislation to take a much more consumer-oriented approach to lawyer discipline.

Queensland was not the first Australian state to move the administration of lawyer discipline out of professional associations and into an independent agency. ${ }^{3}$ Nor was it the first

* Professor of Law, University of Connecticut School of Law. I would like to thank the Centre for Public, International and Comparative I aw, T.C. Bcirne School of J aw, University of Quccnsland for rescarch support during my fellowship. I am also deeply grateful to Drs Linda Haller, Reid Mortensen and Christine Parker for providing me with invaluable comments on an earlier draft of this article. Finally, I would like to thank the individuals who agreed to speak with me, and who generously provided me with their time and insights, in an effort to help me better understand the lawyer discipline reforms in Quecnsland.

1 For example, the American Bar Association described the state of US lawyer discipline as "scandalous": Special Committec on Evaluation of Disciplinary Fnforcement, Problems and Recommendalions in Disciplinary Enforcement (ABA, 1970). See also the discussions of lawyer discipline in M.J. Powell, "Professional Divestiture: 'The Cession of Responsibility for I awyer Disciplinc" (1986) 11 I aw $\&$ Social Inquiry 31; II.W. Arthurs, "The Dead Parrot: Does Professional Self-Regulation Lxhibit Vital Signs"" (1995) 33 Alberta Lam Reviem 800; M. Davies, "Ihe Regulatory Crisis in the Solicitors' Profession" (2003) 6 Jegal Elhics 185.

2 Sir David Clementi's relatively recent report on lawyer regulation in Lngland and Wales reveals the intractability of some of the problems: D. Clementi, Reviem of he Regulatory Framemork of Legal Services in Sngland and Wales: Tinal Report, December 2004.

${ }^{3}$ Western Australia adopted reforms in the 1980s which removed the discipline function from professional associations and put it in the hands of an independent Legal Practice Board, Complaints Committee and Disciplinary Tribunal. Sce F. Shinnick, F. Bruinsma and C. Parker, "Aspects of Regulatory Reform in the I,cgal Profession: 
state to establish a discipline agency with a consumer protection focus. The earlier discipline reforms have been critiqued, however, on the ground that they essentially "patched on" consumer protection functions to traditional self-regulatory processes. ${ }^{4}$ Moreover, the reforms in other states were often deficient in the remedies available to legal consumers. ${ }^{5}$ The Legal Profession Act 2004 (Qld) borrows from other states' approaches. ${ }^{6}$ One obvious question is whether Queensland learned from earlier mistakes - or did it repeat them?

In late 2006, a little more than two years after the effective date of the Act, I talked to many of the professionals and lay people who participate directly in the regulation of lawyers in Queensland. ${ }^{7}$ I attempted through these conversations to learn more about Queensland's lawyer discipline reforms, in the hope that I could gain a fresh perspective on how best to address some of the problems that continue to plague other jurisdictions as they struggle to improve their lawyer discipline systems. I found that the players in the Queensland process were working well together within the new discipline structure - which is a radical departure from the pre-existing system - to determine the best ways in which to implement the goals of the Act.

While lawyer regulation in Queensland is still in transition, it is not too soon to make some preliminary observations about the reforms. On the whole, the new regulatory system appears well conceived and is superior to the previous mechanisms for handling complaints against barristers and solicitors. There is much that other jurisdictions can learn from Queensland's reforms. At the same time, there are still some ways in which Queensland's lawyer discipline system can be improved. And so while recognising that the lawyer discipline reforms in Queensland can still be termed "a work in progress", this article will describe some of the significant changes that have occurred to date, raise some questions about the structure and operation of the current system, and make some suggestions for the future.

\section{A Brief History of Lawyer Discipline in Queensland}

The Australian courts have consistently maintained their inherent authority to impose discipline on lawyers. ${ }^{8}$ Nevertheless, professional associations of solicitors and barristers historically were given - or assumed - most of the responsibility for disciplining Australian lawyers until the end of the 20 th century. ${ }^{9}$

Australia, Ircland and the Netherlands" (2003) 10 Inemational Foumal of the Legal Profession 237, 245. New South Wales created an independent lawyer discipline agency in 1993: Legal Profession Reform Act 1993 (NSW).

4 C. Parker, "Regulation of the Lthics of Australian Legal Practice: Autonomy and Responsiveness" (2002) 25 Universily of Nem South Wales Jam Fournal 676, 690.

5 Ibid, 691 .

6 Qucensland's reforms borrow heavily from the I cgal Profession Act 1987 (NSW): R. Mortensen and I.. I Ialler, "Legal Profession Reform in Queensland" (2004) 23 Unizersity of Queensland Lam Fournal 280, 282. It also incorporates certain provisions of the national Model Jams: National Jegal Profession Model Bill (2004).

7 I interviewed 17 justices, solicitors, barristers, lay people, and regulators, including some individuals directly affiliated with the Quecnsland I aw Socicty and the Quecnsland Bar Association. In most cases, the intervicws were conducted with the promise of confidentiality and accordingly, references in this article to particular interviews do not include the names of the individuals with whom I spoke.

8 G.L. Dal Pont, Lamyers' Professional Responsibility (Melbourne, 'I'homson, 3rd edn, 2006), 512.

${ }^{9}$ Scc I). Weisbrot, Australian Jamyers (Mclbournc, Jongman Cheshirc, 1990), 193, 199-201. 
In Queensland, the Law Society Act 1927 (QId) established the Queensland Law Society as an incorporated body, created a tribunal of the Law Society ("the Statutory Committee") to hear complaints against solicitors, and gave it the power to strike them off the roll. ${ }^{10}$ The court retained ultimate jurisdiction over solicitor discipline, however, and the Statutory Committee's decisions could be appealed to the courts. During the 1920s, the Law Society was also given the authority to monitor solicitors' trust accounts and in 1930 it received the power to decline to issue solicitors' practising certificates. ${ }^{11}$

In contrast, the Queensland Bar Association, which was formed in 1903, was a voluntary association of barristers and it had no statutory authority to impose discipline. ${ }^{12}$ It was, in essence, a "toothless tiger". ${ }^{13}$ When it received what appeared to be a possibly meritorious complaint about a member, the Bar Committee (the Association's Board of Directors) would refer the matter to an ad hoc committee that would investigate and make a recommendation. Other than encouraging barristers to voluntarily undertake to make certain changes, or removing a barrister from membership of the Bar Association, it had no direct power over its members. In very rare cases, it would go to the court and ask that the court use its inherent power to strike a barrister off the roll. ${ }^{14}$

Starting in the $1970 \mathrm{~s}$, serious questions began to be raised about the effectiveness of lawyer self-regulation throughout Australia. In New South Wales, where the most rigorous and extensive study of lawyer discipline was conducted, the Law Reform Commission concluded that "a significant number of complaints against lawyers are not dealt with fairly and effectively". ${ }^{15}$ The Commission also noted that problems arising out of matters that concerned the ordinary consumer, including overbilling, neglect of client matters and lack of competence, were not being handled as disciplinary matters. ${ }^{16}$ In subsequent years, growing concerns about the efficacy of lawyer self-regulation led to recommendations in several Australian jurisdictions that lay persons participate in the discipline hearing panels and that ombudsmen review the discipline process run by lawyers.

In 1985, Queensland's Parliament enacted legislation establishing a Lay Observer and creating the Solicitors Disciplinary Tribunal. ${ }^{17}$ The Tribunal was a lower level tribunal which would hear matters in panels of two solicitors and one lay person. Unlike the Statutory Committee, which was composed exclusively of solicitors, the Solicitors Disciplinary Tribunal could not strike off or suspend a solicitor. ${ }^{18}$ In 1997, the Statutory Committee and the Solicitors Disciplinary Tribunal were replaced by the single Solicitors Complaints Tribunal, which heard discipline matters in panels composed of two solicitors and one lay

${ }^{10}$ J aw Socicty Act 1927 (Q1d), ss 3, 5.

11 'Trust Accounts Act 1923 (Qld); L. Haller, "Waiting in the Wings": The Suspension of Queensland Lawyers" (2003) 3 Queensland Universily of Technology Lam and Fuslice Foumal 397, 416-17.

12 L. Haller, Discipline of the Queensland Legal Profession (2006) (unpublished dissertation on file with author), $123-4$

13 Interview \# 2 with Queensland Supreme Court Justice (Brisbane, 5 October 2006).

14 I Ialler, supra n. 12, 124-6, 131.

15 New South Wales Reform Commission, Legal Profession Discussion Paper No 2, Complaints, Discipline and Professional Standards, Part 1 (1979), 7.

16 Ibid, 7-9

17 Quecensland I aw Society Act Amendment Act 1985 (Qld).

18 L. Haller, "Solicitors' Disciplinary Hearings in Queensland 1930-2000: A Statistical Analysis" (2001) 13 Bomd Lam Review 1, 4. 
person. A Legal Ombudsman was also appointed, with the power to bring charges against solicitors and to appeal decisions of the Solicitors Complaints Tribunal. ${ }^{19}$

By this time, the Australian state Attorneys-General recognised the need for more serious structural changes in lawyer regulation and some jurisdictions began to move lawyer discipline out of the control of the professional associations. ${ }^{20}$ Efforts to implement significant structural changes in lawyer discipline were accelerated during the late 1990s due to scandals involving lawyers or inadequate lawyer discipline. ${ }^{21}$ Queensland endured its own serious scandal in the late 1990s when it was discovered that Gold Coast solicitor Harry Smith had misappropriated more than \$6 million from his elderly clients, and managed to singlehandedly deplete the Queensland Legal Practitioners Fidelity Guarantee Fund. ${ }^{22}$

By 2001, the Standing Committee of Attorneys-General adopted a resolution to develop national model laws ("Model Lams") that would help to promote uniformity in the regulation of lawyers. ${ }^{23}$ While work was underway on the Model Lams, a new scandal broke out in Queensland in 2002 involving Brisbane's Baker Johnson law firm. This issue dominated the headlines of the Brisbane Courier-Mail, which published more than 17 stories reporting egregious overcharging by the firm and the Law Society's failure to act on more than 100 complaints against the firm. ${ }^{24}$ As a result of the scandal, Queensland's Attorney-General and its Minister of Justice asked the Legal Ombudsman to investigate the Queensland Law Society's handling of the Baker Johnson matter, as well as its general complaints handling procedures. The Legal Ombudsman issued a damning report of the Law Society's complaints handling procedures, and recommended that an independent body handle complaints because of the Law Society's "conflict of interest in maintaining a regulatory role as well as maintaining their $[$ sic $]$ role as a Society to benefit the profession". ${ }^{25}$

By mid-2003, the Law Society reluctantly recognised that it must give up much of its involvement in lawyer discipline. ${ }^{26}$ The Bar Association seemingly welcomed changes that would create more power to discipline barristers. ${ }^{27}$ The judiciary did not oppose the establishment of an independent lawyer discipline agency that was overseen by the Government. ${ }^{28}$

19 Quecnsland I aw Society Amendment Act 1997 (Qld); Quecnsland J aw Socicty Act 1952 (Qld), s 6AI(1), inserted by Queensland Law Society Legislation Amendment Act 1997 (Qld), s 9.

20 By the late 1990s, Western Australia and New South Wales had already implemented some changes (sec supra n. 3), although the professional associations continued to investigate complaints against lawyers. By 1996, Victoria permitted persons to make complaints to the Jegal Ombudsman or the professional associations and the Ombudsman could conduct an investigation: Legal Profession Act 1996 (Vic), ss 138, 143.

21 Sec eg R. Bond, "ASIC. Must Get Tough on Managers", The Australian (Sydncy), 6 January 1999, 26; D. Carrigg, "l"und Woes Hang Over Lawyers", Hobart Mercury (Hobart), 1 May 1999; R. Campbell, "Disciplinary Plan for I awyers; Will Incident Prompts MI A's Move", Canberra Times (Canberra), 30 August 1997, A6; I laller, supra n. $12,158 \mathrm{n} .180$.

22 A. Fvans, "Qucensland Fidelity Compensation 1990-2004: The End of the Moncy Trec" (2004) 23 Universily of Queensland Lam Joumal 397, 402; P. Whittaker and R. Callinan, "Claims Against Lawyers Outstrip l"unds", Courier Mail (Brisbanc), 20 Fcbruary 1999, 4.

23 Dal Pont, supra n. 8, 16.

24 See I Ialler, supra n. 12, 158-9. The story also received extended national coverage: sec S. Balough, "We Win and You Pay", The Weekend Australian (Sydney), 17 August 2002, 24.

25 I.cgal Ombudsman, The Queensland Lam Sociely and Baker Fohnson Jamyers (2003), 2, 5, 7-8.

26 See C. Griffith, "No Longer a Law Unto Themselves", Courier Mail (Brisbane), 10 May $2003,34$.

${ }_{27}$ I Taller, supra n. 12, 131-2, 136.

28 In 1999, Queensland's Attorney General had circulated a Green Paper on reform that would place lawyer regulation in the hands of an independent agency which would be supervised by the judiciary: Qucensland Green Paper, Legal Profession Reform (1999). 'The judiciary opposed that proposal. It did not want to oversee such an agency due to concern that it would cxpose the court to "undue criticism and controversy", that it would distract 
Apparently contemplating an upcoming state election, and feeling unable to wait for the release of the Model Lams, Queensland's Parliament passed the Legal Profession Act 2003 (Q1d), which was based in part on a consultation draft of the Model Laws, and provided, inter alia, for the establishment of an independent lawyer discipline agency. ${ }^{29}$ After the $M o d e l$ Laws were released, but before the Legal Profession Act 2003 (Qld) commenced, the Legal Profession Act 2004 (Qld) was passed, which restated much of the 2003 Act and added some additional provisions concerning, inter alia, multidisciplinary partnerships, the fidelity fund and the practice of foreign law. ${ }^{30}$

\section{The Content and Implementation of the Legal Profession Act 2004 (Qld)}

\section{A. The Legal Profession Act 2004}

The Legal Profession Act 2004 (Q1d) significantly altered the structure of lawyer discipline in Queensland and broadened its focus. The Act provides for the appointment by the Attorney-General of a Legal Services Commissioner ("the LSC"), who may be a lay person or a lawyer. ${ }^{31}$ The Act gives the LSC the exclusive power to receive complaints and, where appropriate, to dismiss them without investigation. ${ }^{32}$ The LSC may refer those complaints to the Law Society or the Bar Association for investigation and recommendations, but he reviews the recommendations and has the ultimate authority to determine whether a matter should be prosecuted. ${ }^{33}$ If the LSC decides to proceed with a matter, he has the exclusive authority to prosecute the case. ${ }^{34}$

Under the Act, complaints that are not immediately dismissed are divided into three categories. Complaints of "professional misconduct" allege conduct that would "justify a finding that the practitioner is not a fit and proper person to engage in legal practice" and includes "a substantial or consistent failure to reach or maintain a reasonable standard of competence or diligence". ${ }^{35}$ Complaints of "unsatisfactory professional conduct" allege conduct that "falls short of the standard of competence and diligence that a member of the public is entitled to expect of a reasonably competent Australian practitioner". 36 "Professional misconduct" and "unsatisfactory professional conduct" complaints (hereinafter "conduct matters") are heard in separate tribunals, as described below. Complaints involving "consumer disputes" are disputes between a person and a legal practitioner that "do not involve an issue of

the court from its core function, and that the court lacked the resources to adequately fund such a system. Sec S. Monk and S. Ryan, "Judges Attack Overhaul Bid", Courier Mail (Brisbane), 20 September 1999, 9; Interview \# 5 with Quecnsland Supreme Court Justice (Brisbane, 12 October 2006).

29 Mortensen and I Iallcr, supra n. 6, 280-1.

30 'The Act was again amended in May 2006: Legal Profession Amendment Act 2006 (Qld) No 24.

31 J.cgal Profession Act 2004 (Qld), s 414.

32 Ibid, s 259

3.3 Ibid, ss 265(2), 273. The masculine form is used here because the current I cegal Scrvices Commissioner is a male.

34 Ibid, s 276 .

35 Ibid, s 245 (1).

36 Ibid, $\mathrm{s} 244$. The Act also details specific types of conduct that constitute unsatisfactory professional conduct or professional misconduct, including, inter alia, charging excessive legal costs and conviction of a serious offence: ibid, s 259 (6)(b)-(c). 
unsatisfactory professional conduct or professional misconduct". ${ }^{37}$ The LSC may suggest to the parties that they enter into mediation to resolve these disputes, but mediation is voluntary and consumer disputes will not result in a hearing. ${ }^{38}$

The Act represents a significant departure from the prior system, not only because it establishes an independent agency to handle complaints about lawyers, but because of its decidedly consumer-oriented tilt. Problems with lawyer competence and diligence-which had previously been largely ignored by those in charge of lawyer discipline are now expressly a basis for discipline. The standard applied in determining unsatisfactory professional misconduct is no longer what the community of lawyers thinks about the conduct, but rather what a member of the public is entitled to expect of a reasonably competent Australian legal practitioner. ${ }^{39}$ The Legal Profession Act 2004 (Qld) provides for a mechanism to mediate minor consumer disputes, so that clients can obtain some relief. The Act also provides that all disciplinary action taken against an Australian legal practitioner must be maintained by the LSC on a discipline register which must be available on the LSC's website. ${ }^{40}$

One significant way in which the Act differs from the Model Lams is in its use of two separate tribunals to hear discipline matters. ${ }^{41}$ Professional misconduct complaints are heard by the Legal Practice Tribunal, which is composed of members of the Queensland Supreme Court, and is constituted by any one of its members. ${ }^{42}$ The single justice, who alone constitutes the Legal Practice Tribunal, sits with one member of a lay panel and one member of a practitioner panel who are to "help" him in hearing and deciding a discipline application. ${ }^{43}$ The Legal Practice Tribunal's decisions may be appealed to the Queensland Court of Appeal. ${ }^{44}$ Unsatisfactory professional misconduct complaints are heard by the Legal Practice Committee, which is composed of two lawyers and a lay person. ${ }^{45}$ Decisions by the Legal Practice Committee may be appealed to the Legal Practice Tribunal, and, with leave, to the Court of Appeal. ${ }^{46}$

The 400-plus page Act includes many other provisions concerning the regulation of lawyers. Some reflect the fact that while Queensland has moved away from self-regulation by lawyers, there remain co-regulatory aspects to the reforms. For example, the Act gives the Law Society and the Bar Association the exclusive power to issue annual practising certificates. ${ }^{47}$ In addition, the Act retains the Law Society's power to investigate solicitors' trust fund accounts. ${ }^{48}$

37 Legal Profession Act 2004 (Q1d), s 262.

$38 \mathrm{Ibid}, \mathrm{s} 263(2)$.

$39 \mathrm{Ibid}, \mathrm{s} 244$. In contrast, the prior common law definition looked to the standard of professional conduct "obscrved or approved of by members of the profession of good repute and competency": I. I Ialler, "Imperfect Practice under the Legal Profession Act 2004 (Qld)" (2004) 23 Unizersity of Queensland Lam Fournal 411, 417-18, quoting Re $R$, a pracilioner of the Supreme Courl $\lceil 1927\rceil$ SASR 58, 61.

40 Legal Profession Act 2004 (Qld), s 296(1), (4).

4 The Model Laws contemplate that all disciplinary procedings would be brought before a single disciplinary tribunal: National Legal Profession Model Bill (2004), s 4.7.1.

42 I.egal Profession Act 2004 (Qld), s 429.

43 Ibid, ss $280(1), 437(3)$.

44 Ibid, s $292(1)$.

45 Ibid, s $282(1), 469(2)$.

46 Ibid, ss 293(1), 294(2).

${ }^{47}$ Ibid, ss 44-45. While this is not a new development for the Law Society, it is a new power for the Bar Association.

48 Queensland Law Society Act 1952 (Q1d), s 531; Trust Accounts Act 1973 (Qld), s 29; Legal Profession Act 2004 (Q1d), s 204. 


\section{B. The Implementation of the Legal Profession Act 2004}

An early and symbolically significant change under the new Act is that Queensland's first Legal Services Commissioner is not a lawyer. ${ }^{49}$ Commissioner John Briton has a background in dispute management and previously worked as the State's Anti-Discrimination Commissioner and the State Director of the Human Rights and Equal Opportunity Commission. ${ }^{50} \mathrm{He}$ views the Act as "consumer protection legislation". ${ }^{51}$ His consumer orientation quickly manifested itself when he implemented a system at the Legal Services Commission for handling clients' inquiries in which trained Complaints Officers would attempt in appropriate cases to resolve a problem immediately by placing a call to the lawyer. ${ }^{52} \mathrm{He}$ also decided that even though the Act did not require the LSC to post the names of lawyers who were found to have engaged in unsatisfactory professional conduct, the information would appear on the Legal Services Commission's website. ${ }^{53}$

At present, initial calls about a lawyer are received at the Legal Services Commission or at the Queensland Law Society. ${ }^{54}$ All inquiries are logged into a computerised case management system that was adapted from the one already being used by the Law Society, ${ }^{55}$ and both the Law Society and the Commission can access the full inquiry log concerning any lawyer. In cases where it appears that the problem is simply one of poor communication or a minor misunderstanding, the Commission's Complaint Officers or the Law Society's Client Relations Centre may attempt informally to resolve the problem by placing a call to the lawyer. ${ }^{56}$ If it appears that the matter cannot be resolved, or if the allegations are of such a serious nature that they may constitute a conduct matter, the caller is advised to file a complaint with the Legal Services Commission. ${ }^{57}$

At its inception in July 2004, the Legal Services Commission inherited 938 complaints. Two years later, it had reportedly eliminated most of the complaint backlog, reducing the

49 This is a departure from the practice in New South Wales and Victoria, where the only other I cegal Services Commissioners are both lawyers. While the previous incumbents of the superseded Legal Ombudsman role in Quecnsland and Victoria were non-lawyers, they lacked the broad investigative and prosecutorial powers of the Legal Services Commissioners.

${ }_{50} \mathrm{ttp}$ ///www.lsc.qld.gov.au/commissioner.htm.

51 J. Briton, unpublished lecture at University of Queensland, T.C. Beirne School of Law, 26 October 2006. See also Qucensland J cegal Services Commission, Annual Reporl 2005-06 (2006), 9 (noting that the Act "cmbeds the regulation of the legal profession firmly within the legal protection context").

52 Sec Queensland I cgal Services Commission, ibid, 16. This approach was no doubt borrowed from the similar practice used by the New South Wales Legal Services Commission.

5.3 J. Briton, The Legal Services Conmission-An Overviem (2004), available at http://www.lsc.qld.gov.au/ speeches $/ 20040$ verview.pdf.

${ }^{54}$ T cegal Services Commission, supra n. 51, 37. Although the Quecnsland Bar Association also receives a few inquiries, the Bar Association does not encourage them and directs callers to the Legal Services Commission if they wish to make a complaint. Qucensland Bar Association, How to Make a Complainl, http://www. qldbar.asn.au/ 2199.html.

55 J. Briton, The Legal Services Commission-One Year On, 26 October 2005, 18, available at http://www. Isc.qld. gov.au/speeches/QU'IOct05.pdf. Unfortunately, the Queensland Bar Association did not maintain computerised records of the complaints it received and the I.cgal Services Commission does not have access to most complaints lodged against barristers prior to 2004: Interview \# 9 with Legal Services Commission regulator (Brisbane, 17 October 2006).

${ }^{56}$ See Queensland Law Society, http://www.qls.com.au/wse/lwp/workplace/lut/Your+Solicitor/If+you+ I lave+Conecrns/Client+Relations+Centre; J cegal Services Commission, supra n. 51, 16.

57 'The method for filing the complaint is described on the Commission's website: http://www.lsc.qld.gov.au/ complaint.htm\#6. 
number of pending pre-Act complaints to 29.58 After initially relying heavily on the investigative resources of the Law Society and the Bar Association, which handled most of the investigations in the LSC's first year of operation, by mid-2006 only about half of the investigations were being referred to the Law Society or the Bar Association for investigation, while the remainder were handled by the Legal Services Commission. ${ }^{59}$

Although the Legal Profession Act 2004 (Qld) does not expressly provide for private discipline, some complaints are resolved privately. Complaints that allege unsatisfactory professional conduct may be resolved informally with the Legal Services Commission if the lawyer will take restorative steps such as apologising to the complainant, waiving some or all of a fee, or implementing better office systems. In such cases, the Commission "will use the leverage the Act gives [it] to seek to persuade [lawyers] to do whatever they reasonably can to put things right, and to prevent similar mistakes in the future" ${ }^{60}$ If the L.SC is satisfied with the steps taken by the lawyer, the complaints are dismissed in the "public interest", based on the theory that there is no public interest in prosecuting them. At present, almost $15 \%$ of all conduct matters are dismissed on "public interest" grounds. ${ }^{61}$

Due to the Legal Services Commission's ability to resolve the complaint backlog, it has been able to devote some of its resources to its own investigations and initiatives. Specifically, it has initiated investigations that have revealed that law firms specialising in conveyancing were charging undisclosed mark-ups or surcharges on outlays. ${ }^{62}$ It has also issued guidelines for practitioners on charging outlays and on advertising personal injury services. ${ }^{63}$

Although the news about the Queensland reforms is generally very positive, there are some deficiencies in the Act that hamper the ability of the Legal Services Commission adequately to address consumer concerns. As previously noted, consumer disputes can only be resolved through voluntary mediation. Compensation orders cannot be awarded to clients for consumer disputes. Even in conduct matters, compensation awards are limited to $\$ 7,500$ for pecuniary loss. ${ }^{64}$ Clients who have suffered a greater pecuniary loss must undertake the expense of litigation if they seek to recover for the damage done by their lawyers.

I also encountered a few concerns about the manner in which the current system is functioning. Most notably, some of the lay members on the panel that assists the justices who serve as the Legal Practice Tribunal felt that they were not given all of the relevant materials in a timely manner, that their views were not honestly solicited, and that they were providing a symbolic rather than a true advisory function. One lay participant described her experience as follows:

"It was overwhelming. I had absolutely no background on how it would operate. Not being a lawyer, I didn't know. There were no criteria on which to base a decision. I thought, 'how on earth did you make a decision?" "65

While the lay members said that they did not necessarily disagree with the outcomes of the Legal Practice Tribunal, they felt inhibited in terms of raising questions and talking during

${ }_{58}$ Legal Services Commission, supra n. 51, 13.

59 Ibid, 16.

6) Ibid, 10,18 .

${ }^{61}$ Ibid, 18.

${ }^{62}$ Ibid, 20.

${ }_{63}$ Sec http://www.lsc.qld.gov.au/policics/guidelines/pdf.

${ }^{64}$ Legal Profession Act 2004 (Qld), s 290 (3).

${ }^{65}$ Interview \# 15 with Iegal Practice Tribunal lay panel member (telephone interview, 6 November 2006). 
hearings. They also perceived that the lawyers who assisted the Tribunal were somewhat inhibited in expressing their views. ${ }^{66}$

I did not speak to lay members of the Legal Practice Committee, which is comprised of lawyers and lay persons, but a former member of the Solicitors Complaints Tribunal (an immediate predecessor to the Legal Practice Committee) reported that her views were not seriously regarded by the lawyer members in the decision-making process. This individual felt that she was viewed by the lawyers as "an appendage" and someone "who did not have a brain". ${ }^{67}$ One lawyer member of the Legal Practice Committee noted that "lay observers can be intimidated, but you shouldn't do it". ${ }^{68}$ He also observed that an impediment to lay members taking a strong stand against a proposed resolution of a discipline matter is that they would need to write dissents from majority decisions, which they may feel ill-equipped to do. This observation appears to be confirmed by the fact that there have been no dissents written by lay members of the Legal Practice Committee and only one dissent written by a lay member of its predecessor, the Solicitors Complaints Tribunal.

On the positive side, there is evidence that both the Law Society and the Bar Association are not only co-operating in this transition, but are using their powers to grant practising certificates in ways that should reduce complaints about lawyers. In at least one case when the Legal Services Commission had concerns about a solicitor, the Law Society required a physical examination of the solicitor and only renewed the practising certificate with qualifications. ${ }^{69}$ The Bar Association has reported that when it recently had concerns about the competency of certain barristers, it only issued practising certificates after the lawyers submitted undertakings about the procedures they would implement to avoid problems in practice. ${ }^{70}$

Finally, although I heard no complaints about the cost, the new discipline system is not inexpensive. The budget of the Legal Services Commission in 2005-6 was $\$ 1.83$ million. The Bar Association staffs its investigations with barrister volunteers, but the Law Society expended an additional $\$ 2$ million of public funds to administer the complaints handling system during that period. When the cost of the Legal Practice Tribunal and the Legal Practice Committee were included, the total cost of administering the complaints handling system was more than $\$ 4$ million. ${ }^{71}$

\section{Future Questions and Challenges}

Less than three years after the passage of the Legal Profession Act 2004 (Qld), the transition has been made to an independent lawyer discipline agency with a consumer-oriented focus. Problems with neglect of client matters and failure to communicate are receiving attention

66 Interview \# 14 with Legal Practice 'Tribunal lay panel member (Brisbane, 25 October 2006).

67 Intervicw \# 8 with lay member of Solicitors Complaints Tribunal (Brisbane, 16 October 2006). Another former lay member of the Solicitors Complaints 'Tribunal did not share this view and strongly believed that his input on that tribunal was valucd: Intervicw \# 10 with lay member of Solicitors Complaints Tribunal (Jrisbanc, 17 October 2006). It appears that some of the differences in lay experiences may have been due, in part, to differences in gender or professional status.

68 Interview \# 12 with lawyer member of Legal Practice Committee (Brisbane, 23 October 2006).

69 Intervicw \# 4 with Qucensland I aw Socicty cmployec (Brisbanc, 11 October 2006).

${ }^{0}$ Interview \# 13 with Queensland Bar Association officer (Brisbane, 24 October 2006).

71 J.egal Services Commission, supra n. 51, 43. 
and, in many cases, are being rapidly resolved. The Legal Services Commission, the Queensland Law Society and the Queensland Bar Association are working together to investigate complaints and have effectively eliminated the complaint backlog. It is clear that the lawyer discipline system is more efficient and more responsive than it was before the passage of the Act. Thus, the Act has seemingly accomplished many of its intended goals.

There are, however, some important questions that deserve further thought at this stage in the reforms. Some relate to the challenge of balancing consumer protection functions and traditional lawyer discipline interests. ${ }^{72}$ For example, is Queensland's new system paying adequate attention (or too much attention) to its consumer protection role? How should it resolve complaints when there is a conflict between the individual consumer's interests and protection of the public? In other words, a solution that satisfies the individual clientperhaps the return of fees-is not necessarily the best solution for the general public, which may later be harmed in the same way by the same lawyer.

Another important question is to whom should "consumer protection" be afforded when one is talking about protection from lawyers? Clearly protection extends to current clients who have been harmed by their lawyers. It also extends, under the rhetoric of "public protection", to future clients who may be subjected to the same types of misconduct. Does it extend, as well, to non-clients who are adversely affected when lawyers and their clients work together in ways that harm others? And does consumer protection ever extend to corporate clients, who are usually better able than individuals to take care of themselves in their dealings with lawyers?

Further questions arise when considering the types of misconduct that a discipline agency with a consumer protection orientation might pursue. Lawyers are unquestionably engaged in a business, but they are not the same as the businesses of car salesmen or shopkeepers. Lawyers have competing ethical duties to the courts, to their clients and to the public. They are paid to make complex judgment calls every day. But should clients be able to pursue complaints about every mistake including mistaken judgments - that a lawyer makes? And if not, which ones should be addressed? And at what cost?

There are also some more concrete questions and challenges that remain with respect to the structure and implementation of the new discipline system. Some of the questions arise simply because Queensland has tried some new approaches, including the appointment of a Legal Services Commissioner who is not a lawyer. Some questions arise from the continuation of pre-existing procedures, such as the involvement of the Law Society in handling inquiries from the public. Some arise from the effort to incorporate lay views into an adjudicatory structure that features significant attorney and judicial involvement in lawyer discipline. I will explore some of these questions and challenges below.

Is a lay legal services commissioner desirable? Queensland appears to be the first jurisdiction in the common law world where the lawyer discipline system is run by a non-lawyer. ${ }^{73}$ When

72 Christine Parker has persuasively argued that it does not appear possible for one agency to fully meet the goals of both consumer empowerment and lawyer discipline and that two separate regimes are required: Parker, supra $\mathrm{n}$. 4, 693. Unfortunately, at least in the United States, where the discipline systems are already underfunded, it is highly unlikely that two systems that address lawyer conduct will be funded. Accordingly, I am interested in identifying how a single-system model might come closest to accommodating the interests of consumer protection and traditional lawyer discipline.

73 Fngland, Wales and Australia have had J ceal Ombudsmen who were non-lawyers, but their role typically was one of oversight and they did not have the exclusive power to make prosecutorial decisions or prosecute discipline complaints. See also supra n. 49. 
considering the history of lawyer regulation, this is a seismic change. Lawyers have long maintained that they need to regulate their own conduct in order to preserve their independence from the state. ${ }^{74}$ They have also argued for involvement in the discipline process on the theory that only lawyers can understand the pressures and competing obligations that are placed on them in practice. ${ }^{75}$ These arguments continue to have traction, although by the late 20th century, experiments began with lay oversight to address concerns that external supervision of lawyer discipline was needed. ${ }^{76}$

More recently, with the emergence of independent Legal Services Commissions in Australia, there has been consideration of whether the Legal Services Commissioner must be a lawyer. The drafters of the national Model Lams did not address the question. ${ }^{77}$ The Legal Profession Act 2004 (Qld) makes possible the appointment of a lay Legal Services Commissioner, providing that the Commissioner must be "familiar with the nature of the legal system and legal practice" but may be "a person who is not an Australian lawyer". 78

John Briton is Australia's first non-lawyer Legal Services Commissioner and some see the fact that he is a non-lawyer as an important symbolic step. Virtually everyone I spoke to noted the importance that the public no longer view the lawyer discipline process as a case of "Caesar judging Caesar", and the initial appointment of a lay Commissioner helps to allay that concern. As a practical matter, however, most of them felt that the most important question was whether the Commissioner was the "right" person for the job, regardless of whether that individual was a lay person or a lawyer. Among the people I spoke to, it was lawyersand not the non-lawyers - who were more likely to believe that it was important in the short term for the Commissioner to continue to be a non-lawyer. As one lay person explained, "the public has little interest in this or knowledge about it ... The public is not overly concerned with who [the Legal Services Commissioner] is". 79

One interesting lesson to be learnt from Queensland's reforms is that having a non-lawyer serve as the Legal Services Commissioner appears not to lead to adverse consequences. Moreover, apart from the possible symbolic advantage to having a non-lawyer serve as Legal Services Commissioner during a time when there might be lingering public suspicion of the lawyer discipline system, there are potentially two practical advantages as well. In Queensland, where there are fewer than 7,000 practising lawyers, ${ }^{80}$ it is likely that a

74 M.II. Frcedman, Lawyers' Silhics in an Adversary System (Indianapolis, Bobbs-Mcrrill, 1975) 9-24; R.W. Gordon, "The Independence of Lawyers" (1988) 68 Boston University Lam Reviem 1, 2-10; D.B. Wilkins, "Who Should Regulate Iawyers?" (1992) 105 Harvard Jam Reviem 801, 812-13.

75 See eg Weisbrot, supra n. 9, 195; T'. Ross, "Knowing No Other Duty: Privity, The Myth of Llitism, and the Transformation of the J cegal Profcssion" (1997) 32 Wake Forest Law Reviem 819, 835; Wilkins, ibid, 816 n. 79.

76 'The United Kingdom first started using a Lay Observer in 1980, but he proved to be ineffective in his oversight of the J aw Society and the Solicitors' Complaints Bureau: sec J.F. Gilbert, "Profession in Crisis?" (1989) Nem Lam Joumal, 28 April, 583. 'The Legal Services Ombudsman for Lngland and Wales was created by the Courts and I,cgal Services Act 1990; the Scottish I cegal Scrvices Ombudsman post was cstablished that same year: sce I aw Reform (Miscellaneous Provisions) (Scotland) Act 1990, s 34. Legal Ombudsmen began to appear in Canada and Australia shortly thereafter: see eg I aw Society of British Columbia, Benchers Bulletin (December 1993); I cegal Profession Act 1993 ('las), s 82.

77 The National J cegal Profession Model Bill refers throughout chapter 4 to the "appropriate authority", without specifying who should perform that role.

78 J cegal Profession Act 2004 (Q1d), s 414(2)-(3).

79 Interview \# 14 with Legal Practice 'T'ribunal lay panel member (Brisbane, 25 October 2006 ).

so There were 5,850 solicitors with practicing certificates on 1 July 2005: J cgal Scrvices Commission, supra n. 51 , 49. There are almost 900 barristers with practising certificates in Queensland: see Queensland Bar Association, Barristers' Jirectory, http://www.qldbar.asn.au/section/3.html. Not all of these individuals practise in Queensland. 
lawyer-commissioner would know personally many of the Queensland lawyers about whom complaints are made - and their advocates, as well. In addition, in a legal culture where, for barristers, Queen's Counsel and Senior Counsel attain those positions based on the judgments of their peers and the judiciary, it would be exceedingly difficult for someone who has worked within the legal community to seemingly contradict that judgment by pursuing a complaint against someone who has achieved that rank. Moreover, the Legal Services Commissioner may only serve for a maximum of 10 years, ${ }^{81}$ and may need to resume law practice thereafter. This could make the job of deciding how to handle certain complaints all the more difficult, especially if that lawyer-commissioner someday wishes to practise law in Queensland.

There is, in addition, another advantage to having a non-lawyer serve as the Legal Services Commissioner. Lawyers are acculturated to the norms of the legal profession, which are sometimes at odds with ordinary notions of morality and the interests of the public. It is important in a lawyer discipline agency designed to protect the public that there be someone in authority with a non-lawyer's perspective. That perspective helps to ensure that complaints about certain lawyer misconduct will not be "overlooked" or dismissed, especially where the conduct conforms with professional norms but violates ordinary notions of morality.

An example of the advantages of having a non-lawyer Legal Services Commissioner was recently illustrated in Legal Services Commissioner $v$ Mullins. ${ }^{82}$ In that case, a discipline complaint was filed against a Queensland barrister who did not reveal when settling a personal injury automobile accident case that he had recently learned that his client was seriously ill with cancer. The barrister continued to rely in mediation on the claim that his client had a 27 year life expectancy when he knew that this life expectancy was very unlikely due to the client's illness. While many lawyers might take the conventional advocate's view that the barrister was simply preserving privileged information and being a zealous advocate for his client, ${ }^{83}$ a non-lawyer would readily see that by allowing the insurance company to settle the case believing that his client had a 27 year life expectancy, the barrister was committing fraud. This was, in fact, the view taken by the lay Legal Services Commissioner, who pursued the complaint and obtained a reprimand and a $\$ 20,000$ fine against a highly-regarded member of the Bar. ${ }^{84}$ It is less likely that a legally-qualified commissioner-or at least one who had previously practised in Queensland - would have had the courage to prosecute the complaint.

Before leaving this topic, one other important question to consider is whether Queensland's Legal Services Commissioner is afforded sufficient independence, regardless of whether the LSC is a lay person or a lawyer. The answer appears to be "yes". The Legal Services Commissioner is appointed by the Attorney-General, but may not serve for more than 10 years. There is no requirement that the Attorney-General consult with any constituency about the appointment. The LSC reports annually to the Attorney-General, who tables the report with Parliament. ${ }^{85}$ The annual report is available to the public. The Legal

${ }^{81}$ Legal Profession Act 2004 (Qld), s 415.

$82\lceil 2006\rceil$ I.PT 012.

83 Indeed, in the Mullins case, the barrister sought the advice of senior counsel, who advised him that he was not required to reveal the information during the mediation (ibid, 5).

${ }^{84}$ Legal Profession Act 2004 (Qld), s 9.

85 Ibid, s 311. 
Services Commission is funded by payments from the Legal Profession Interest on Trust Accounts Fund, and those payments are approved by the Attorney-General. ${ }^{86}$ The LSC can seek budget enhancements as required at any time and has done so successfully. ${ }^{87}$ Thus, the LSC is independent from those whom he investigates and prosecutes, ie, solicitors and barristers, and from their professional organisations. The LSC is also largely independent from the judiciary, which has an institutional interest in the perception that lawyers are behaving ethically, but may also retain ties with the bar ${ }^{88}$ Although the LSC is directly accountable to the Government, some level of accountability to the public is desirable, and it is far preferable that the oversight reside in those who are not being regulated by the LSC.

Is the Legal Services Commission dealing adequately mith consumer protection issues? It seems clear that the Queensland Legal Services Commission is committed to a model of individual consumer protection, and does not view that function as subsidiary to the discipline function. Significant resources are devoted to informally resolving consumer concerns of existing clients. In some cases, these efforts may include obtaining agreements from lawyers to pay clients money in order to resolve consumer dissatisfaction. ${ }^{89}$ Thus, while the LSC has no power to make compensation orders, the Commission and the Law Society will sometimes informally arrange for compensation in appropriate cases. Likewise, the Legal Services Commission is now treating fewer complaints as "consumer disputes" and more as "unsatisfactory professional conduct", which gives it more leverage to work out dispositions that are likely to satisfy individual consumers. ${ }^{90}$ In other words, the Legal Services Commission is working within the Act - and at times, finding creative ways to do so- to satisfy many consumer concerns.

The main area in which the Legal Services Commission may not be adequately protecting consumers is when clients are harmed by negligent legal work. Traditional consumer protection agencies protect consumers against overcharging, fraud and safety violations - but not neglect. As previously noted, however, lawyers are not typical vendors of goods and services. They sell their advice, their advocacy and their legal drafting skills. The question therefore arises as to whether the Legal Services Commission should attempt to address consumers' complaints about mistakes that lawyers make when they perform those services.

The LSC currently does not pursue most complaints arising out of negligent legal work, except negligence relating to the mishandling of client funds. ${ }^{91}$ The Legal Services Commission's website states, under "What the Commission cannot do":

"The disciplinary scheme under the Legal Profession Act 2004 is not intended to be an alternative forum to the courts for hearing and deciding claims of negligence against lawyers. The Commission might consider taking disciplinary action against legal practitioners who have been obviously and demonstrably negligent but, generally speaking, legal consumers who believe their

86 Ibid, ss 208-11.

87 Lmail from Dr Lyn Aitken, Policy and Research Coordinator, Queensland Legal Services Commission, to I.cslic I cevin, 12 March 2007.

88 Of course, the LSC, like all litigants, cannot be completely unconcerned with the views of the judiciary, since the I cgal Services Commission is dependent on the I cgal Practice Tribunal for favourable rulings.

89 Interview \# 4 with Queensland Law Society employee (Brisbane, 11 October 2006).

90 T.egal Services Commission, supra n. 51, 16.

91 This policy apparently results in the dismissal of a large number of complaints. More than $30 \%$ of the Commission's complaints are dismissed on the grounds that they are not the type of matter that the Commission will handle. A large number of those complaints allege negligence: Interview \# 16 with Legal Services Commission regulator (Brisbane, 26 October 2006). 
lawyers have been negligent will have to take them to court to prove they were negligent and should take independent legal advice accordingly." ${ }^{92}$

While the website suggests that these matters are outside the Commission's jurisdiction, in fact the LSC has the jurisdiction to pursue complaints that a lawyer acted negligently, including negligent advice given by lawyers to their clients. The definition of "unsatisfactory professional conduct" under the Act includes conduct "that falls short of the standard of competence and diligence that a member of the public is entitled to expect of a reasonably competent Australian practitioner". ${ }^{93}$ This is a classic negligence standard. The real reasons for not prosecuting most of these cases is that they are hard to prove and that consumers can instead pursue their remedies in court. ${ }^{94}$

But this approach does not bear up well under scrutiny. Sound advice and careful work go to the heart of the services that lawyers are supposed to provide to clients, and if the work or advice is negligent, clients can be seriously harmed. Moreover, clients often have no other recourse because of Australia's continued recognition of advocates' immunity from suit for the conduct of a case in court or for work "intimately connected" with a case in court. ${ }^{95}$ The high cost of litigating negligence issues makes suit impractical in many other cases. The Commission's failure to pursue these claims against incompetent or negligent lawyers means that the lawyer can continue to harm the public in ways far more serious than a failure to return phone calls, which the Commission now routinely pursues.

There is no question that negligence cases can be difficult to prove and that the cost of Queensland's lawyer discipline system is already significant. But when decisions are being made about which matters to pursue in the name of "consumer protection", efforts must be made to resist pursuing the "easy" cases and routinely — as a standard policy — turning away the harder ones. This is especially true when the difficult cases may have caused significantly more damage to a client and the type of misconduct can cause substantially more future risk to the public.

Is the Legal Services Commission over-focusing on small consumer issues? The preceding section begins to raise the question of whether the Commission is too focused on small-scale consumer issues. As one barrister noted, the danger with the structure of the new Legal Services Commission is that it may become a bureaucracy. A lawyer discipline body that views itself as a traditional consumer protection agency may tend to over-focus on small-scale consumer issues and on measures like processing time for complaints, and could lose sight of the bigger picture - which includes all types of lawyer misconduct. Although on balance, this does not appear to be the case with the current Legal Services Commission, ${ }^{96}$ one example of a decision that arguably over-focuses on the "small stuff" is the Commissioner's Guidelines for Charging Outlays and Disbursements, with its retroactive application and its

${ }^{92} \mathrm{http} / / /$ www.lsc.qld.gov.au/about.htm\#4.

93 I.cgal Profession Act 2004 (Qld), s 244.

${ }_{94}$ Interview \# 16 with Legal Services Commission regulator (Brisbane, 26 October 2006). In addition, the Legal Scrvices Commission's website says that it "might consider taking disciplinary action against legal practitioncrs who have been obviously and demonstrably negligent", suggesting that it will take some "easy" cases.

${ }^{95}$ Dal Pont, supra n. 8, 126, 134-8.

96 The rhetoric and the actions of the current Legal Services Commissioner reflect an intention to pursue both the smaller matters that bother consumers and the larger ethical violations. Sce John Briton, "The System for Dealing with Complaints: 'The Commission's Approach", 5 March 2006, 5-6, available at http://www.lsc.qld.gov. $\mathrm{au} /$ speches/ BAQ050306.pdf; sec also supra nn. 81-83 and accompanying text. 
high compliance costs for what will often be a minimal return to clients. The Guidelines advise solicitors not only on how to handle these issues prospectively, but that they should review their files and refund to clients any undisclosed mark-ups or surcharges or other charges in excess of the amounts actually paid that were charged after 1 July 2004. ${ }^{97}$ This pronouncement effectively requires solicitors to review all of their billing since that date and attempt to confirm that all amounts - including postage and filing fees-were properly and accurately charged to clients. This time-consuming and costly undertaking for solicitors could be expected to yield relatively small refunds, if any, for clients.

In contrast, the Commission has not yet specifically directed initiatives against malfeasance in large firm corporate practice, focusing instead on matters that mainly affect individual clients. While clients of large corporate firms are generally better able to protect themselves than individual consumers, a lawyer discipline agency should not overlook the fact that most lawyers' work is performed for corporate clients. ${ }^{98}$ Not all of these businesses are large or wealthy. Moreover, there can be little doubt that lawyer misconduct occurs in large law firms. Large firm lawyers sometimes act, for the benefit of their corporate clients, in ways that constitute professional misconduct. ${ }^{99}$ These lawyers may also act in ways that harm their corporate clients. For instance, there is every reason to believe that overbilling occurs in these law firms ${ }^{100}$ and guidelines with respect to hourly billing would remove much of the uncertainty that is known to be associated with that type of billing. Hopefully the Legal Services Commission will soon use its "consumer protection" mandate to pursue initiatives that reach into larger law firm practice, where lawyer misconduct also occurs.

Are initial inquiries being handled in a consistent fashion? Initial inquiries regarding problems with a Queensland lawyer are currently received in two places. More than two-thirds of all inquiries go to the Queensland Law Society and the remainder go to the Legal Services Commission. ${ }^{101}$ This arrangement is no accident. The Law Society's website states that if consumers are not sure whether they have cause for complaint, they may contact either the Queensland Law Society or the LSC. ${ }^{102}$

Both the Law Society and the Legal Services Commission will attempt to resolve some inquiries informally, although their focus appears to differ slightly. The Law Society's website refers individuals to its Client Relations Centre (CRC), which it describes as "an early intervention service". ${ }^{103}$ Much of the Law Society's focus appears to be on its "effectiveness lines.pdf.

${ }^{98}$ For example, there is evidence that almost two-thirds of all Chicago lawyers' time is devoted to the corporate sector and that two thirds of Chicago lawyers' income derives from corporate clients: J.P. Heinz, R.L Nelson, R. Sandefur and E. I aumann, Urban Lamyers: The New Social Siruclure of the Bar (Chicago, University of Chicago Press, 2005), 43.

99 A recent example can be secn in the charges that partners in Melbourne's Clayton Utz law firm engaged in professional misconduct - including the destruction of documents and possible perjury - during their representation of British American Tobacco Australia Services in a lawsuit brought against it to recover damages suffered by a lung cancer victim. See R. Wallace, "Lawyers for Big 'lobacco Accused" The Australian (Sydney), 21 December $2006,5$.

100 Sec Briton, supra n. 51; J.G. I.crman, "A Double Standard for I awyer Dishonesty: Billing Fraud Versus Misappropriation" (2006) 34 Hofstra Law Reviem 847.

101 T.egal Services Commission, supra n. 51, 15, Table 4.1.

102 Queensland Law Society, "What to Do if you are Concerned", www.qls.com.au/wse/lwmp/workplace/ !ut/p/s.7_0)M5.

103 Ibid. It further explains that "the earlier a problem or potential problem is referred to the CRC, the greater the likelihood the CRC. will be able to assist the solicitor and the client to reach a mutually satisfactory outcome" (ibid). 
in resolving concerns between consumers and practitioners . . . without situations escalating to a point where a formal complaint [is] made to the Legal Services Commissioner". ${ }^{104}$ During the period October 2004 to January 2005, only 3.1 per cent of all inquiry matters received by the CRC resulted in a formal complaint being lodged with the Legal Services Commission. ${ }^{105}$

In contrast, the Legal Services Commission also attempts to resolve some inquiries informally before they become complaints, but it seems less concerned than the Law Society with resolving matters before complaints are filed. So, for example, the Legal Services Commission website mentions, but does not stress, the availability of its Inquiry Officers to try to resolve some problems informally. ${ }^{106}$ It does not track or report the number of inquiries it resolves.

This subtle difference in orientation may be causing the Law Society to encourage individuals to resolve matters with their lawyers when the Legal Services Commission would encourage the same individuals to file a complaint. One reason for the difference could be that the Law Society focuses more on individual consumer satisfaction than the Legal Services Commission, which is more mindful of the need to protect the public at large. A less charitable explanation is that the Law Society's early intervention approach is also designed to help solicitors avoid the embarrassment, expense and potential exposure that comes from a complaint being filed. In either event, there is unquestionably some difference in approach. A printed brochure available at the Law Society said that matters not suitable for mediation included situations where the facts appear to warrant prosecution of the solicitor for "professional misconduct", ${ }^{107}$ while the Legal Services Commission will not try to resolve a matter where it should be prosecuted for either "professional misconduct or "unsatisfactory professional conduct". The chances of inconsistency are increased by the fact that virtually everyone associated with the discipline process admits that the meaning of "unsatisfactory professional conduct" is not clear and remains to be fleshed out by decisions of the Legal Practice Committee, the Legal Practice Tribunal and the Court of Appeal.

A further source of inconsistency appears in the practice of the Legal Services Commission - but not the Law Society - to consider a lawyer's inquiry history before attempting to resolve a matter informally. Lawyers who are the source of multiple inquiries may be engaging in a pattern of low-level neglect, incompetence or misconduct, and this pattern arguably should be considered before attempting to resolve a new matter informally. While the Legal Services Commission reportedly routinely checks the inquiry database to determine whether a lawyer has previously been the subject of inquiries before deciding whether to try to resolve a matter informally, it does not appear that the Law Society's client relations officers - who also have access to the database - routinely consider the particular lawyer's inquiry history before making this determination. Yet failure to consider inquiry histories may result in the repeated informal resolution of problems involving lawyers who engage in a continuing pattern of misconduct, as described below.

The apparent lack of consistency in the handling of initial inquiries raises questions about the wisdom of continuing to receive inquiries in two different places. The problem might be

$104 \mathrm{Ibid}$; also Interview \# 4 with Queensland Law Society employee (Brisbane, 11 October 2006).

105 Quccnsland I aw Socicty, Annual Reporl 2004-2005, 19.

106 See http://www.lsc.qld.gov.au/complaint.htm\#3.

107 Quecnsland I aw Society, Brochure, Clienl Relations Centre. 
addressed by clearer guidelines from the LSC about which types of cases are appropriate for informal resolution, and which are not. There is, however, no obvious economic or other advantage to the public in having the Law Society handle these initial inquiries. The public funds that pay for complaints-handling by the Law Society could be funnelled to the Legal Services Commission so that it could field all inquiries. Moreover, no matter how carefully and conscientiously it handles these inquiries, the Law Society will always be susceptible to the charge that it is protecting its own. There is administrative inefficiency in the current approach, as well. Sometimes individuals make inquiries to both the Law Society and the Legal Services Commission, hoping that they will get a "better answer" from one entity if they don't like the one they receive from the other. ${ }^{108}$ This is wasteful and inefficient from everyone's perspective.

Should the Bar Association and the Lam Society remain involved in investigations? A question that is closely related to the preceding discussion is whether the Queensland Bar Association and the Law Society should continue to be involved in conducting investigations for the Legal Services Commission. During the initial transition in 2004, it seemed sensible for the Law Society and the Bar Association to continue to investigate complaints, as they had the personnel and established systems to do so. Today, it is no longer clear whether they should continue to perform these functions, both because of the perceived conflict of interest and because of the inefficiency of this approach. There is, in addition, a question mark over whether the Bar Association, which uses volunteers to perform investigations, will be able to keep up with the work flow on a voluntary basis. At this point, it is difficult to articulate a good reason why investigations should continue to be conducted by the professional associations. ${ }^{109} \mathrm{~A}$ preferable approach would be for the professional associations to relinquish these responsibilities to the Legal Services Commission, so that it could conduct all investigations of lawyers.

Many common law jurisdictions have, at some point, relied upon professional associations to investigate complaints against lawyers. The practice in the United States began in the 1870 s and continued for more than a century. ${ }^{110}$ By that time, the American Bar Association's study of lawyer discipline systems had declared the state of lawyer discipline "scandalous", in part because of the ways in which professional associations handled the investigation of lawyers. ${ }^{111}$ While closer oversight of professional associations' investigative efforts may have reduced the criticism, it would not eliminate the problem that such a process is duplicative. Nor would it eliminate the spectre of "Caesar judging Caesar".

The duplicative consequences of sharing the investigative function with professional organisations can be seen in New South Wales, where the Law Society Council and Council of the Bar Association remain involved in discipline investigations and retain the power to dismiss complaints. The Legal Services Commissioner monitors the Councils' investigations of complaints and reviews their decisions to dismiss complaints or to impose

108 Interview \# 4 with Queensland Law Society employee (Brisbane, 11 October 2006).

100 The onc cxplanation that I heard that had any saliency was that members of the Jar Association are better able to understand the practice of law by other barristers than are investigators. But since some of the lawyers who work for the T SC. were barristers, this argument is unpersuasive.

110 See L. Levin, "The Case for Less Secrecy in Lawyer Discipline" (2006) 20 Georgetomn Journal of Legal Ethics, 1, 15-19. The professional associations were criticised, inter alia, for delays in responding to complaints and for their reluctance to pursue investigations of prominent lawyers.

111 Special Committec on Fvaluation of Tisciplinary Enforcement, supra n. 1, 1. 
reprimands. ${ }^{112}$ During 2005 , more than 700 complaints were referred to the Councils for investigation and resolution, which represented more than 25 per cent of all complaints received by the Legal Services Commissioner. In addition to the monitoring function that the Commissioner was required to perform for the typical investigation, there were 76 requests for review of the Councils' decisions to dismiss, and 46 reviews occurred during the reporting period. ${ }^{113}$

Costly duplication of effort also occurs in the investigation of complaints in Queensland. At present, the Law Society's investigators are employed by the Law Society and paid from Government funds. After the investigator thoroughly investigates a matter and reviews it with the manager of investigations, the Law Society submits a report to the LSC, ranging from five to 40 pages. ${ }^{14}$ The LSC then carefully reviews the report. If the matter is prosecuted, the Commission's Legal Officers - who typically supervise the investigations of the cases they pursue - must learn the facts of those cases for the purposes of trying them before the Committee or the Tribunal. Rather than retain this time-consuming and duplicative process, the Government funds that now pay for the Law Society's investigative efforts should be directed toward hiring additional Legal Services Commission investigators who could perform all discipline investigations.

Is "minor misconduct" being handled effectively and in a manner that protects the public? Minor lawyer misconduct may now be resolved in a variety of ways in Queensland. First, as previously noted, an inquiry about lawyer misconduct may be resolved informally by the CRC or the Legal Services Commission before it ever becomes a complaint. Second, if the matter cannot be resolved and an individual files a complaint, it may be classified as a "consumer dispute", which is a complaint that does not rise to the level of "unsatisfactory professional conduct" or "professional misconduct". 115 The range of conduct that constitutes a "consumer dispute" is not entirely clear, but it appears that it could include failure to attend to matters promptly or a failure to return phone calls. Third, the complaint may be classified as "unsatisfactory professional conduct", but a "public interest" dismissal may be granted where the LSC decides not to pursue a complaint after the lawyer agrees to take steps to improve his or her office's practices. Fourth, if the complaint cannot be resolved to the LSC's satisfaction, the matter may proceed to the Legal Practice Committee for a hearing and, where appropriate, the imposition of a sanction.

The effort to address "minor" misconduct is a significant improvement on the prior discipline system, which rarely afforded assistance to the public when minor problems arose involving lawyers. As the preceding paragraph illustrates, however, most "minor" misconduct is resolved privately and never becomes known to the public. In cases where the conduct is truly aberrational and the harm to clients minimal, this approach is probably appropriate. But certain types of "minor" misconduct - including repeated neglect of client matters and failure to communicate with clients - is more problematic, and is conduct about which the public undoubtedly would want to know.

Consistent rules for the prosecution of "minor" misconduct are needed so that patterns of complaints and evidence of recidivism are being adequately tracked and considered by the

112 Legal Profession Act 2004 (NSW), s $688(\mathrm{f})-(\mathrm{g})$.

113 New South Wales Office of the Jegal Services Commissioncr, Annual Report 2005-2006, 7-8, 35.

114 Interview \# 4 with Queensland Law Society employee (Brisbane, 11 October 2006).

115 I cegal Profession Act 2004 (Qld), s 262. 
Legal Services Commission. There is significant recidivism among lawyers who are disciplined in the United States ${ }^{116}$ and there is evidence of recidivism among lawyers who have received sanctions in Queensland. ${ }^{117}$ While the fact that some lawyers receive a number of complaints does not, standing alone, necessarily mean that any misconduct occurred, it may reflect a pattern of misconduct that should be carefully considered in order to adequately protect the public.

Thus, careful attention must be paid not only to the informal dispositions of "inquiries", as discussed in the preceding section, but also to the categorisation of "consumer disputes" and the use of "public interest" dismissals for complaints that allege unsatisfactory professional misconduct. ${ }^{118}$ In cases where "minor" misconduct appears to have occurred in more than one instance, the LSC should consider carefully whether to approve a "public interest" dismissal or whether to seek a disposition that enables the public to learn of the misconduct, at least for some period of time. ${ }^{119}$ In addition, if a lawyer who receives a "public interest" dismissal is later the subject of another conduct complaint, the Legal Practice Committee or the Legal Practice Tribunal should be able to consider that information when imposing a sanction in the subsequent matter. If necessary, in order to ensure that the information can be revealed in a subsequent discipline proceeding, any practitioner who obtains a "public interest" dismissal should be required to stipulate that in the event that a future discipline complaint results in a prosecution, the Legal Services Commission can bring this information to the attention of the relevant tribunal. Finally, any recidivism that occurs after public interest dismissals are granted should be carefully tracked so that the Legal Services Commission can evaluate the effectiveness of its approach.

Are the disciplinary bodies constituted in the most effective fashion? Queensland's use of a twotier system for hearing discipline matters and its decision to have a Supreme Court justice sit as the upper Legal Practice Tribunal is unique. Linda Haller has previously critiqued this two-tier structure, noting its potential for confusion with respect to whether discipline matters should be heard in the Legal Practice Committee or the Legal Practice Tribunal. ${ }^{120}$ Now that the new system has been implemented, it is clear that she was correct. In addition, the use of two separate bodies is an ineffective use of resources and poses some risk that it will result in inconsistent and confusing case law. The present system also discourages meaningful input from the lay participants - and some lawyers - in the process. The better approach would be to eliminate the Legal Practice Tribunal, to allow a single body to decide all conduct matters, and to give the LSC the power to impose public reprimands in certain prescribed cases.

116 T.cvin, supra n. $110,1$.

117 See Haller, supra n. 18, 23; Briton, supra n. 55, 4. One former member of the Solicitors Complaints 'Tribunal noted that "a lot of repeat offenders" who had previously been disciplined came before that body: Intervicw \# 8 with lay member of Solicitors Complaints 'Tribunal (Brisbane, 16 October 2006).

11 . The I.SC. has indicated that in the future, he will be using the "public interest" dismissals more and the "consumer dispute" category less. Both categories lead to a non-public disposition of a complaint. The advantage of using the "public interest" dismissal is that the I.SC can more effectively negotiate with the practitioner to put systems in place that will avoid complaints in the future.

119 See infra nn. 141-42 and accompanying text. Prior complaints reportedly are considered in the I.SC's decision making with regard to public interest dismissals: Interview \# 9 with Legal Services Commission regulator (Brisbane, 17 (Oetober 2006). But it is unclear whether there are any clearly defined standards with respect to how prior complaints are to be weighed in the process.

120 I Ialler, supra n. 39, 421-26. 
The reasons why a two-tier discipline system was adopted in Queensland are not clear, but it appears that the decision may have been made for both practical and symbolic reasons. From a practical perspective, if a Supreme Court justice is going to hear some discipline cases as a matter of first impression, the justice should not have to hear every minor misconduct complaint. This makes sense from the perspective of preservation of judicial resources, but it begs the question of whether a Supreme Court justice should be hearing lawyer discipline cases in the first instance.

Why the Supreme Court justices agreed to constitute the Legal Practice Tribunal can only be imagined, ${ }^{121}$ but the decision was probably motivated by political realities and by the desire to convey important messages to various constituencies. From a political perspective, the Court may have felt the need to offer the Government a compromise after it rejected Government efforts to make the judiciary responsible for supervising a new lawyer discipline agency. ${ }^{122}$ The Court's participation in the Legal Practice Tribunal may also reflect its desire to send messages to three different audiences. First, the involvement of a Supreme Court justice in the Legal Practice Tribunal conveys to the public the importance that the judiciary attaches to the lawyer discipline process and to the public's complaints against lawyers. Second, it conveys to lawyers the seriousness of discipline proceedings and the judiciary's concern about lawyer misconduct. And third, during a time when the legislature was becoming deeply involved in the regulation of lawyers, it conveys to the legislature that the judiciary intends to retain some direct and regular control over the discipline of lawyers. ${ }^{123}$

One question to consider, however, is whether the symbolism is worth the price, not only in terms of judicial resources and administrative costs, ${ }^{124}$ but in other respects. Because the Legal Practice Tribunal is a Supreme Court justice, the LSC may feel reluctant to bring "professional misconduct" charges before the Tribunal where the act fits within the statutory definition but the harm is relatively minor. ${ }^{125}$ The LSC may fear that the Tribunal will feel that the LSC is "wasting" the justice's time. If the Commission is reluctant to prosecute as "professional misconduct" certain behaviour that falls within that statutory definition, this may skew the Commission's decisions as to how it should define "professional misconduct", at a time when it is also struggling to define "unsatisfactory professional conduct" and "consumer disputes". This may, in turn, contribute to the development of case law that is at odds with the statutory definition of the terms.

The structure of the Legal Practice Tribunal also discourages lay input, and possibly input from practitioners as well. The advisory panels to the Legal Practice Tribunal are relatively

121 The precise involvement of the Supreme Court in the shaping of the Act is unclear, but there is no question that the judiciary's view was solicited, and that the Government took into account the role the judiciary wished to play in the lawyer discipline process when it drafted the legislation.

122 Sce supra n. 28.

123 See eg Chief Justice P. de Jersey, "Ihe Supreme Court and the Legal Profession Act 2004 (Qld)" (2004) 23 Universily of Queensland Lam Fournal 289,290 (noting the judiciary's concern that "any reform uphold the Supreme Court as the source of a legal practitioner's professional legitimacy").

During the period when the proposed legislation was under discussion, the judiciary struggled to define its own role with respect to the regulation of lawyers. While insisting on its right to retain admission powers over lawyers, it almost simultancously ceded authority to oversec the discipline process. Compare F. Metcalf, "Judges Call for Ultimate Say on Who Can Practise", Courier Mail (Brisbane), 26 March 1999, 11 with Monk and Ryan, supra n. 28.

124 The I.cgal Practice Tribunal and the I.cgal Practice Committec are administered by different entitics and require the appointment and co-ordination of separate panels.

125 See Intervicw \# 16 with I.cgal Services Commission regulator (Brisbanc, 26 October 2006). 
large - composed of six solicitors, six barristers and seven lay persons ${ }^{126}$ — which means that any individual panel member typically hears no more than one case a year. This makes it difficult for lay panel members, in particular, to achieve an understanding of the issues or to attain a comfort level with the decision-making process. Moreover, under the Act, the Supreme Court justice is the ultimate decision-maker, and the lay panel member and the practitioner panel member play a decidedly secondary role. ${ }^{127}$ Members of those panels indicated that it is difficult to feel free to present their views or to disagree with a Supreme Court justice, particularly when any individual panel member only rarely participates in the discipline process. One lay participant felt that lay people were simply participants in the process for "perception" or symbolic purposes. ${ }^{128}$ Even some lawyer-participants felt inhibited when participating in the process. As one solicitor panel member observed, "it is awe inspiring for solicitors who don't normally sit on that side of the bench - it is not a familiar situation". ${ }^{129}$

Something important is lost if lawyers on the panel are inhibited from providing meaningful input into decision-making about lawyer conduct. The vast majority of discipline is imposed against solicitors, but Supreme Court justices almost invariably practised as barristers. As one lawyer asked, "[h] ow does he know what is the norm in the life of solicitors?"130 And even the justices' experiences as barristers often occurred decades in the past. Thus, the decision-making process could benefit from the uninhibited input of practitioners, who could provide an understanding of the context in which problems arise.

Lay people also have an important perspective to offer the Tribunal that is being lost in the current process. Lay people have a sense of the real world and of proportionality. Since they are not as concerned with maintaining the reputation of the legal profession as are lawyers and judges, they can more freely apply their sense of proportionality to the facts of a case. While the lay people whom I interviewed uniformly felt that they could not speak freely when assisting the Tribunal, their comments provide insights into their potential contributions to the process. For instance, one lay person described trying (unsuccessfully) to convince the Tribunal and the solicitor panel member in a high publicity case that a lawyer did not deserve to be struck off. ${ }^{131}$ Echoing a view I heard often, one lawyer noted, "I think that the profession is harder on lawyers who did wrong than are consumers because it is in our interest to get rid of the sharks". ${ }^{132}$

Lay people bring not only a sense of proportionality to the discipline process, but also their ordinary notions of morality. Virtually all of the lay people I interviewed recalled their initial surprise about the lack of connection in lawyer discipline cases between "the law" and notions of justice. As one lay person noted, "lots of lawyers don't think there is a difference between 'law' and 'justice"”. ${ }^{133}$ Another observed, "a lot of what happened didn't have to do

126 http://www.lsc.qld.gov.au//1pc.htm.

127 That role is to "help" the J cegal Practice Tribunal in hearing and deciding the discipline matter: I cegal Profession Act 2004 (Qld), s 437(3). The reason for this structure is unclear. It may be because the judiciary jealously guards the independence of the court, including in the imposition of discipline (see supra $\mathrm{n}$. 123). It also may have been thought unseemly for a Supreme Court justice, a lawyer and a lay person to have equal standing on a tribunal.

128 Interview \# 14 with Legal Practice 'Tribunal lay panel member (Brisbane, 25 October 2006).

129 Interview \# 11 with I cegal Practice Tribunal solicitor panel member (telephone interview, 19 October 2006).

130 Ibid.

1.31 Intervicw \# 6 with I cegal Practice Tribunal lay panel member (Brisbanc, 12 October 2006).

132 Interview \# 12 with Legal Practice Committee member (Brisbane, 23 October 2006).

13.3 Interview \# 6 with J cegal Practice Tribunal lay pancl member (Brisbane, 12 October 2006). 
with justice or ethics it had to do with the legal rule". ${ }^{134}$ This same individual recalled a lawyer member of a panel who did not want to discipline a solicitor "because the conduct didn't fit within a pigeonhole - and my attitude was 'bugger that'". ${ }^{135}$ This lay perspective is an important one to be preserved in the process.

For these reasons, the Legal Practice Tribunal should be eliminated and a single decisionmaking body composed of lay people and practitioners should hear all complaints alleging unsatisfactory professional conduct and professional misconduct. Serious consideration should still be given, however, to the question of how to ensure that lay people are adequately heard. ${ }^{136}$ One way of accomplishing this end might be to use three-person panels composed of at least one lay person and one practitioner, while the third person would alternately be a practitioner or a lay person. This might help to change the culture so that everyone involved understands that the views of lay people are as important as those of practitioners. Appeals from decisions of this body could then be taken to a three-judge panel of the Queensland Court of Appeal. ${ }^{137}$

One final, separate problem with the current adjudicatory structure is that enormous resources may be devoted to handling very minor matters. As one lawyer asked, "[w]hy have all this cost over matters involving postage fees?"138 For example, if a lawyer who uses offensive language when addressing a member of the public is charged with "unsatisfactory professional conduct", the complaint would be heard by the Legal Practice Committee. This will require the expenditure of time and effort by the Legal Services Commission's lawyer, the respondent, the respondent's lawyer, and three panel members. The LSC inevitably must consider when making his charging decision whether he wishes to expend resources in this way and the Legal Practice Committee's likely response to its decision to do so. And the Committee - whose practitioner members serve on a voluntary basis - is left to feel that the LSC's charge (which can result in huge defence fees for the respondent lawyer) is disproportionate and that its own time is being wasted on exceedingly "minor" matters. This attitude may result in no imposition of discipline by the Legal Practice Committee so that it can express its displeasure to the Legal Services Commission for bringing the matter. ${ }^{139}$ This

134 Intervicw \# 8 with lay member of Solicitors Complaints Tribunal (Brisbanc, 16 October 2006).

135 Ibid.

136 The feclings of marginalisation reported by lay people did not just arise on the I ecgal Practice Tribunal. One person reported the experience of having her views discounted by lawyers when sitting on the three-member Solicitors Complaints Tribunal, which suggests that this may also be a problem for lay members of the similarlyconstituted Legal Practice Committee. See supra n. 67 and accompanying text.

${ }^{137}$ Thus far, there has been only one appeal to the Court of Appeal from a decision of the I.egal Practice Tribunal or the Legal Practice Committee: Legal Services Commission, supran. 51, 24; Baker v Legal Services Commissioner [2006] QCA 145. It is likely that there has been only onc appeal from the Tribunal's decisions-cren though the stakes are high - because the matter has already been decided by a Supreme Court justice. It can be expected that if a pancl of lay people and practitioners replace the J egal Practice Tribunal, there would be more appeals in serious matters, but it seems unlikely that the total judicial time devoted to discipline matters would be greater than it is under the current system.

${ }^{138}$ Interview \# 12 with Legal Practice Committee member (Brisbane, 23 October 2006). In fact, there has not yet been a reported discipline decision involving postage fees, but this comment may have been a reference to the LSC's Guidelines for Charging Outlays and Disbursements, with its suggestion of possible discipline for non-compliance. Sce supra n. 97 and accompanying text. The lawyer's point, however, was that occasionally very minor matters had been pursued before the hearing bodies, requiring a disproportionate expenditure of money and human resources.

${ }^{139}$ In the case on which the fact scenario is based, the solicitor called her client's ex-husband "a grotesquely ugly man". As soon as the solicitor was contacted about the matter, she offered a written apology, which was refused. The matter ultimately resulted in a finding of unsatisfactory professional conduct for the use of offensive language, but the solicitor was not fined or ordered to pay costs: Jegal Services Commissioner o Johnson [2005] J.PC006/05. 
type of decision may, in turn, chasten the LSC, who may think twice about prosecuting this type of matter in the future. ${ }^{140}$ In turn, the failure to prosecute may eventually send the signal that the LSC will not seek to pursue lawyers for rude or offensive language.

A better approach would be to give the LSC the power to impose minor sanctions - such as a reprimand or a compensation order-on consent. Minor sanctions imposed by the LSC on consent should appear on the L.SC website, ${ }^{141}$ should only be available on one occasion against any particular lawyer, ${ }^{142}$ and should only be imposed for truly minor misconduct. This would enable the charged lawyer to avoid some of the expense associated with extended discipline proceedings, resolve a stressful matter more quickly, and confine the use of the three-person hearing body to situations where more egregious or contested conduct was at issue. It would also reduce the costs of prosecution for an already costly lawyer discipline system.

\section{Conclusion}

There is much to be admired in Queensland's lawyer discipline reforms. For the first time, barristers are subject to a discipline process that can result in an array of sanctions. Complaints against practitioners are being investigated much more quickly and prosecution decisions are being made by an independent agency headed by a non-lawyer. The public are able to learn about the discipline imposed on lawyers, which enables individuals to better protect themselves when they choose to retain counsel. The new discipline system offers much more transparency and credibility than the previous one. It is among the most consumer-oriented discipline systems in the world.

As anyone close to Queensland's lawyer discipline system will admit, however, it is still a work in progress. With the benefit of some experience, it is now possible to identify some changes that would improve the system's responsiveness, its credibility and its efficacy. For example, during the initial transition in 2004 , it made sense for the professional associations to continue to receive inquiries about lawyers, to try to resolve them, where appropriate, and to investigate some complaints. For the reasons previously discussed, it is far from clear whether it is desirable for the professional associations to continue in those roles today. After the experience with a two-tribunal system, consideration should also be given to combining the Legal Practice Tribunal and the Legal Practice Committee into a single adjudicative body. In addition, efforts should be made to increase meaningful lay participation in that body. The Legal Services Commission should be more willing to provide redress for clients who are victimised by negligent legal work, rather than forcing those individuals to go to court.

As complaints handling and other procedures are tested and refined, it is important to keep asking how well Queensland's Legal Services Commission is achieving its dual mandate of

140 See Interview \# 1 with Legal Services Commission regulator (Brisbane, 3 October 2006).

141 This practice is also currently followed in New South Wales: I.cgal Profession Act 2004 (NSW), ss 540(2), $576(\mathrm{e})$.

${ }^{142}$ In the United States, disciplinary counsel typically have the power to impose admonitions on consent, but in many jurisdictions those sanctions are private, and too often they are imposed repeatedly before more serious public discipline is imposed. Sec J cevin, supra $\mathrm{n} .110$. A better practice would be to allow the I.SC to sanction a lawyer for minor misconduct on one occasion only, with the understanding that if there is no further finding of misconduct during a specified period, the information will be removed from the Commission's website. 
consumer protection and traditional lawyer discipline. Consumer surveys are one way to test what is not being done well, but they are less likely to capture the success of the reforms. ${ }^{143}$ Another way of helping to ensure that individual consumer concerns are addressed is to give the LSC the power to impose minor sanctions and make small compensation awards. At the same time, in order to ensure protection of the general public, the Legal Services Commission should carefully track those lawyers who are the subject of multiple inquiries and complaints to ensure that lawyers engaging in persistent low-level misconduct are not consistently "flying under the radar". Recidivism among those who receive sanctions should also be carefully tracked. Published guidelines covering a variety of areas - including hourly billing practices may be a faster means of altering lawyer conduct than case-by-case enforcement efforts.

Finally, as Queensland embraces an independent regulatory model in the area of lawyer discipline, the question naturally arises as to what role, if any, lawyers' professional associations should continue to play in related spheres of regulation. Specifically, the inherent conflict presented by the Law Society's position as a lawyers' guild and a regulator raises questions about the wisdom of its continued involvement in the monitoring of client trust accounts. Similar questions are raised by the Law Society's and Bar Association's role in issuing annual practising certificates. These questions merit careful consideration, with due regard for available resources and the organisational challenges for any lawyer regulatory agency that might attempt to assume so many different responsibilities. Among the issues that should also be considered are possible information asymmetries if the professional associations are unwilling to share all available information, duplication of investigative efforts, the current effectiveness of trust account oversight, and the willingness of the professional associations to make "hard" decisions about practising certificates.

Inevitably, as progress in any system is made, new questions arise concerning its focus and efficacy. Fortunately, Queensland now has a reasonably well-funded and well-staffed discipline system. Moreover, the many individuals who have come together to make the system work are dedicated people, who are making good judgments and who share a common interest in protecting the public. If the progress and choices made to date are any indication, the signs are hopeful that these questions will be addressed soon and that Queensland's lawyer discipline system will come to be viewed as a model for best practices in Australia and throughout the world.

143 Most respondents will not have cause to complain about more than one lawyer, so they will not be able to comment on the changes that have occurred over the last few years. Moreover, satisfied consumers often feel no need to comment; it is often those who are most unhappy with a system that are most likely to respond to consumer surveys. 